2,8 Jahre und bei den Lungenmetastasen 3,4 Jahre. Ein Patient lebte nach Resektion einer Rippenmetastase länger als 5 Jahre. Die höchste Absterbensquote nach Resektion von Lungenmetastasen war in den ersten 2 Jahren, die 5-Jahresüberlebensrate betrug 25\% bei allen Malignomen und 27,9\% nach Carcinommetastase. Die Prognose ist gut bei einem langen Intervall zwischen Operation des Primärtumors und Auftreten der Metastase.

Schlïsselwörter: Pleurametastasen - Mediastinalmetastasen - Rippenmetastasen - Lungenmetastasen.

\title{
175. Ergebnisse nach operativer Behandlung der Lungenmetastasen
}

\author{
S. Kostiainen, P. Appelquist, P. Pantzar und S. Mattila \\ Thoraxchirurgische Universitätsklinik von Helsinki, SF-Helsinki

\section{Results of Operative Treatment of Pulmonary Metastases}

Summary. A total of 59 patients with hematogenous pulmonary metastases were operated in 1955-1977. The 5 -year survival rate was $15 \%$ for the whole series and $32 \%$ for the patients treated in $1972-1977$. The 5-year prognosis was $20 \%$ in solitary metastases and $11 \%$ in multiple metastases. In cases with a disease-free interval of less than 1 year after the primary operation, the 5 -year prognosis was $8 \%$. When the disease-free interval was more than 3 years, the 5 -year prognosis was $30 \%$. The prognosis of osteosarcomas did not differ from that of hypernephromas.

Key words: Pulmonary metastases - Operative treatment.

Zusammenfassung. Insgesamt 59 Patienten wurden wegen Lungenmetastasen extrapulmonaler Malignome in den Jahren 1955- 77 operativ behandelt. Die Überlebensrate war 15\%/5 Jahre im ganzen Krankengut und $32 \% / 5$ Jahre für die Fälle von 1972 - 77. Die 5-Jahres-Prognose für die Fälle mit solitären Metastasen war $20 \%$, mit multiplen Metastasen $11 \%$, für die mit freiem Intervall weniger als ein Jahr von der Primäroperation $8 \%$ und $30 \%$ für die mit freiem Intervall mehr als drei Jahre. Die Prognose der Osteosarkome war nicht schlechter als diejenige der Hypernephrome.

Schlïsselwörter: Lungenmetastasen - Operative Behandlung.

\section{Ergebnisse und Prognose nach Resektion von Lungen- und Lebermetastasen}

\author{
B. Angermann, F. P. Gall, M. Schweiger und S. Hoferichter
}

Chirurgische Klinik mit Poliklinik der Universität (Dir.: Prof. F. P. Gall), Maximiliansplatz, D-8520 Erlangen

\section{Results and Prognosis After Resection of Pulmonary and Liver Metastases}

Summary. The prognosis was better after resection of pulmonary metastases in 131 patients than after removal of liver metastases in 85 patients. The number of removed pulmonary or liver metastases was not decisive for the prognosis. After removal of pulmonary metastases by means of lobectomy, the survival rates were twice as high as after wedge excision, and we also achieved distinctly better survival rates by means of hemihepatectomy with regard to removal of liver metastases as compared to local excision. Twenty-six patients had to be operated on several times because of new pulmonary and liver metastases. The 5-year survival rate was $22 \%$.

Key words: Pulmonary metastases - Liver metastases - Surgery - Prognosis.

Zusammenfassung. Die Prognose war nach Resektion von Lungenmetastasen bei 131 Patienten besser als nach Entfernung von Lebermetastasen bei 85 Patienten. Dagegen spielte die Zahl der entfernten Lungen- oder Lebermetastasen für die Überlebenschance keine entscheidende Rolle. Wurden Lungenmetastasen durch Lappenresektionen entfernt, erreichten wir doppelt so hohe Überlebensraten wie nach Keilexcisionen. Ebenfalls deutlich bessere Überlebensraten erzielten wir mit der Hemihepatektomie gegenüber der lokalen Excision bei der Entfernung von Lebermetastasen. 26 Patienten mußten wegen erneuter Metastasierung in Lunge oder Leber mehrmals operiert werden. Dabei war die 5-Jahres-Überlebensrate $22 \%$.

Schlïsselwörter: Lungenmetastasen - Lebermetastasen - Chirurgie und Prognose. 